\section{Commentary: Toward a more rational approach in pediatric aortic valve repair}

\author{
Hans-Joachim Schäfers, MD
}

In the past 20 years, aortic valve (AV) repair has become an increasingly used treatment modality, mostly for the treatment of aortic regurgitation. The goal of $\mathrm{AV}$ repair is the creation of normal form and function of the valve. AV repair using only visual assessment of AV form has not always yielded reproducible results. ${ }^{1}$ The analysis of geometric parameters of normal aortic cusp and valve form ${ }^{2-4}$ has led to a marked increase in the proportion of repaired valves, and it has improved repair durability. ${ }^{5}$ In particular, measurement of cusp tissue height, ie, geometric height, ${ }^{3}$ and height difference between cusp margins and annular plane, ie, effective height, ${ }^{2}$ have become helpful in choosing the adequate substrates for repair and guiding the repair procedure. Using such a repair concept based on a geometric approach has improved applicability and results of repair. ${ }^{5}$ AV repair has been shown to be associated with a very low incidence of valve-related complications, ${ }^{6}$ and it probably improves postoperative survival. ${ }^{7}$ AV repair is particularly essential for children and adolescents in whom avoidance of anticoagulation is particularly important. In addition, AV repair does not impede somatic growth of aortic root and annulus and-apart from replacement using a pulmonary autograft-allows for normal development until the time of final AV replacement. A wider use of repair in pediatric patients is limited by the morphologic variability of congenital AV disease. In addition, the geometric parameters used for adult $\mathrm{AV}$ repair ${ }^{4-6}$ have not yet been determined for a pediatric or adolescent population.

In this context, the current publication ${ }^{8}$ is an important step forward. Based on echocardiographic examinations, the

From the Department of Thoracic and Cardiovascular Surgery, Saarland University Medical Center, Homburg/Saar, Germany.

Disclosures: The author reported no conflicts of interest.

The Journal policy requires editors and reviewers to disclose conflicts of interest and to decline handling or reviewing manuscripts for which they may have a conflict of interest. The editors and reviewers of this article have no conflicts of interest.

Received for publication May 27, 2021; revisions received May 27, 2021; accepted for publication June 1, 2021; available ahead of print June 4, 2021.

Address for reprints: Prof Dr Hans-Joachim Schäfers, MD, Department of Thoracic and Cardiovascular Surgery, Saarland University Medical Center, Homburg/Saar, Germany (E-mail: H-J.Schaefers@uks.eu).

JTCVS Techniques 2021;8:140

2666-2507

Copyright (C) 2021 The Author(s). Published by Elsevier Inc. on behalf of The American Association for Thoracic Surgery. This is an open access article under the CC BY-NC-ND license (http://creativecommons.org/licenses/by-nc-nd/4.0/).

https://doi.org/10.1016/j.xjtc.2021.06.002

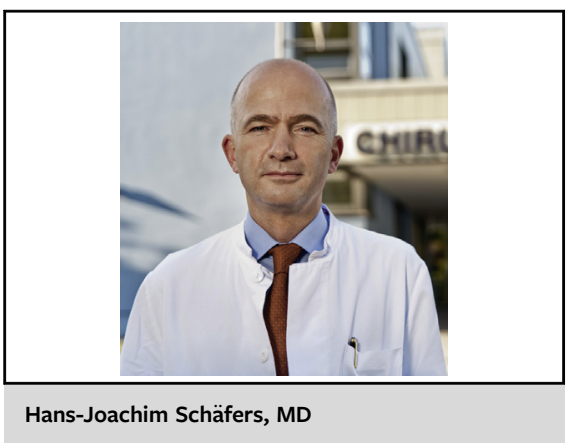

CENTRAL MESSAGE

The analysis of geometric parameters of pediatric aortic

valves is an important prerequisite for reproducible aortic valve repair in this age group.

authors have achieved in a pediatric population what has been done previously for adults, ie, define the important geometric parameters of AV form. Importantly, they have selected normal or near-normal aortic valves and are thus setting the norm. The information will have to be verified by intraoperative measurements. This study ${ }^{6}$ and its information is thus an essential step forward toward geometry-based and rational $\mathrm{AV}$ repair in pediatric patients. It will contribute to wider application of repair and improved reproducibility.

\section{References}

1. Lansac E, Di Centa I, Sleilaty G, Lejeune S, Berrebi A, Zacek P, et al. Remodeling root repair with an external aortic ring annuloplasty. J Thorac Cardiovasc Surg. 2017; 153:1033-42.

2. Schäfers HJ, Schmied W, Marom G, Aicher D. Cusp height in aortic valves. J Thorac Cardiovasc Surg. 2013;146:269-74.

3. Bierbach BO, Aicher D, Issa OA, Bomberg H, Gräber S, Glombitza P, et al. Aortic root and cusp configuration determine aortic valve function. Eur J Cardiothorac Surg. 2010;38:400-6.

4. Tamer S, Mastrobuoni S, van Dyck M, Navarra E, Bollen X, Poncelet A, et al. Free margin length and geometric height in aortic root dilatation and leaflet prolapse: implications for aortic valve repair surgery. Eur J Cardiothorac Surg. 2020;57: 124-32.

5. Matsushima S, Karliova I, Gauer S, Miyahara S, Schäfers HJ. Geometry of cusp and root determines aortic valve function. Indian J Thorac Cardiovasc Surg. 2020;36(suppl 1):64-70.

6. Aicher D, Fries R, Rodionycheva S, Schmidt K, Langer F, Schäfers HJ. Aortic valve repair leads to a low incidence of valve-related complications. Eur J Cardiothorac Surg. 2010;37:127-32.

7. de Meester C, Pasquet A, Gerber BL, Vancraeynest D, Noirhomme P, El Khoury G, et al. Valve repair improves the outcome of surgery for chronic severe aortic regurgitation: a propensity score analysis. J Thorac Cardiovasc Surg. 2014; 148:1913-20.

8. Bouhout I, Chauvette V, Rong W, Raboisson M-J, El-Hamamsy I, Poirier N. The normal aortic valve leaflets effective height in pediatric patients: a guide to aortic valve repair. J Thorac Cardiovasc Surg Tech. 2021;8:135-7. 